\title{
Determinant Factors of SMEs in Adopting E-commerce in Indonesia
}

\author{
Rahayu Ningsih \\ Center of Domestic Trade Analysis \\ Trade Policy Analysis and \\ Development Agency \\ Ministry of Trade \\ Jakarta, Indonesia \\ rahayuningsih75@gmail.com \\ Selfi Menanti \\ Center of Domestic Trade Analysis \\ Trade Policy Analysis and \\ Development Agency \\ Ministry of Trade \\ Jakarta, Indonesia \\ selfimenanti@gmail.com
}

\author{
Sahara \\ Head of Department of Economics, \\ Faculty of Economics and \\ Management, Bogor Agricultural \\ University \\ Bogor, Indonesia \\ sahara_ipb@yahoo.com
}

\author{
Andhi \\ Center of Domestic Trade Analysis \\ Trade Policy Analysis and \\ Development Agency \\ Ministry of Trade \\ Jakarta, Indonesia \\ andhi.stp@gmail.com
}

\author{
R.R Febrinda, \\ Center of Domestic Trade Analysis \\ Trade Policy Analysis and \\ Development Agency \\ Ministry of Trade \\ Jakarta, Indonesia \\ rrfebrinda1202@gmail.com
}

\begin{abstract}
The potential of digital economy in Indonesia in 2025 is predicted to provide added value up to USD 115 billion (McKinsey Study). Meanwhile, the adoption of e-commerce by SMEs in Indonesia still limited. Based on survey of Indonesian E-Commerce Association (IdEA), less than 16 percent of SMEs utilize the marketplace to sale their products. This analysis aims to identify factors that influence SMEs in marketing their products through e-commerce. This study conducted based on case study of SMEs in Yogyakarta by using the Importance Performance Analysis (IPA). IPA conducted by considering internal and external factors that influenced SMEs. It was concluded that the main factors inhibiting SMEs are the lack of knowledge about the marketplace and the ability to look over the market opportunities in digital media. It is recommended to provide business incubator model that is integrated with a training system, mentorship, and access to financing and marketing.
\end{abstract}

Keywords-SME, e-commerce, policy response

\section{INTRODUCTION}

Indonesia is the sixth country with the highest number of internet users in the world after China, the United States of America, India, Brazil and Japan. Based on Indonesian Internet Service Provider Association (APJII), about 132,7 million internet users in 2016 in Indonesia grew up to 7,95\% in 2017 or about 143,26 million users. In 2018, it was estimated that internet users in Indonesia will grow up to $60 \%$.

The growth of Internet users has implicate the surge of marketing using e-commerce platform. Therefore, Indonesian government asserted that improvement efforts are needed on digital economy to achieve economy development by using Information Technology.

E-commerce had been grown significantly as a business platform in Indonesia since 2014. This initiated by the establishment of e-commerce start-up business such as
Lazada, Blibli, Tokopedia, Bukalapak, Elevania and Bhinneka. In 2017 retail development in Indonesia reached $100 \%$, while e-commerce hit the number of $289 \%$ (IDNTimes, 2018). More and more offline merchant moves to online; the widespread of mobile wallet; and same day delivery service demand are some reasons that describe the development of e-commerce.

The SMEs sector's contribution to the economy is quite high at around 60 percent of the national GDP and 98 percent of the workforce. Although the growth of e-commerce is quite good, the utilization of e-commerce platforms by SMEs is still low. The low utilization of e-commerce by SMEs in developing countries is generally due to the lack of technology access. Other factors that also influencing the ecommerce utilization are the lack of ability of SMEs to access financing / capital and produce quality products in accordance with the standards required by the market.

This study aims to analyze the determinant factors that influence the adoption of e-commerce by SMEs in Indonesia in marketing their products. This study used the case study of SMEs in the city of Yogyakarta. The decision to select the city of Yogyakarta as our focus in this study is caused by its large number of SMEs, adequate infrastructure and one of the target areas for a pilot project for government programs related to SMEs Go Online. From the results of this analysis, this study would recommend strategies to improve the use of e-commerce by SMEs.

\section{A. General Condition of SMEs in Indonesia}

In Indonesia, SMEs have an important role as the main of economy activity. It is absorbing human resources; creating new markets; developing domestic economic activity; and also increasing foreign exchange from export activity. Based on BPS (2016), the total of SMEs unit in 1997 in Indonesia are 39,7 million. The number increased up to $45,6 \%$ or 57,8 million in 2013. In 2017, the number of SMEs was 
increasing $9 \%$ or up to 63 million. Nonetheless, the employment rate of SMEs is still low. Only $0,87 \%$ new employment from 2013 to 2017, or around 114 million new employees. Thus the growth is still very low in the term of absorbing labor compared to its potential of being more inclusive in the e-commerce era.

Generally, SMEs have some constraints that inhibit the business development. A study about general constraint that are faced by SMEs (LPPI and BI) showed some internal and external factors. Internal factors comprise difficulties in financing; human resources that do not have the knowledge to understand market's needs; and also accountability. External factors include business climate, infrastructure, and market access. Moreover, SMEs access toward production and market access technology are still simple.

\section{B. Adoption of E-commerce by SMEs in Other Countries}

A research study on increasing market access in Kenya using information and communication technology (ICT) had been conducted by Kiveu and Ofafa (2012). The results showed that there are some constraints on market access by SMEs. Besides the difficulties due to limited information, there are also market liberalization and globalization that caused intense competition on physic market. Another factor that limit market research and analysis to be carried out are high transaction cost; lack of product diversification; and minimal capacity for e-commerce. Existing policies are considered not able to overcome problems in competing SMEs in the global market. E-commerce utilization can benefit SMEs and consumers with increasing marketing efficiency, expanding the market to global markets, facilitating connectivity, reducing business procurement costs by up to $20 \%$ and consumer costs by $15 \%$.

While other studies on how Vietnam SMEs adopt ecommerce had been conducted by Ho (2017). By using exploratory and single case study, this study found that there are factors such as the experience of the employees to manage e-commerce sector, low customer awareness of ecommerce, the unpopularity of electronic payment, and barriers such as lack of capital investment, customer habit, the characteristics of the products, and ineffective planning, that affect the case company's progress towards the ecommerce sector.

A study and analysis on challenges and obstacles in implementing E-commerce in the marketplace in Malaysia had also been carried out (Mukhtar, Ashaari, Rahman and Husin 2016). There are some challenges based on this study: product authenticity, pricing errors, inappropriate images, fraud when transactions and shipping, privacy security and product warranty. All these obstacles have been regulated in the law in Malaysia. The solutions to the challenges given are the existence of regulations regarding electronic transactions; consumer protection; data and privacy protection; regulations on online content; cybersecurity; online dispute resolution and domain name regulations, as well as providing customer service.
Some things that also need to be done in order to increase ICT utilization in SMEs are through promotion to increase public awareness and increase market access, training, improving infrastructure by the government, developing programs / platforms to facilitate access, ensuring the availability of accurate information, and implementing policies for the development of ICT by the government.

Regarding export potential through e-commerce platform in Thailand, Pittawat Ueasangkomsate (2015) found that exporters do not gain positively in export by using ecommerce. Even though based on the analysis, the awareness of SMEs exporters and non-exporters on the benefits of using e-commerce is quite high, reaching $60 \%$ for SMEs exporters.

\section{METHODOLOGY}

This study conducted by using descriptive qualitative and quantitative analysis method with explorative approach. Study performed using primary data - from interview and FGDs, and secondary data from related institutions. Interviews and FGDs were conducted on marketplaces and SMEs to find out the factors that hinder and support SMEs in marketing their products in the marketplace. Determination of these factors was obtained by literature studies and interviews with experts. The results of the interviews that had been conducted are arranged into a questionnaire which was distributed and the results were analyzed using the Importance-Performance Analysis (IPA). The IPA method measures respondent's perceptions related to the performance and importance of factors in order to provide which factor decision makers (e.g., managers) should focus (Martilla and James, 1977). The IPA technique is divided into four quadrants (See Fig.1).

The identified factors separated into two criteria internal and external factor. Internal factors refer to the factors that have significant impact and can be controlled by business owners on the e-commerce adoption. External factor refers to the factors that cannot be controlled by business owners; however, the owners have to adjust and anticipate the external factors in order to maintain their business on track

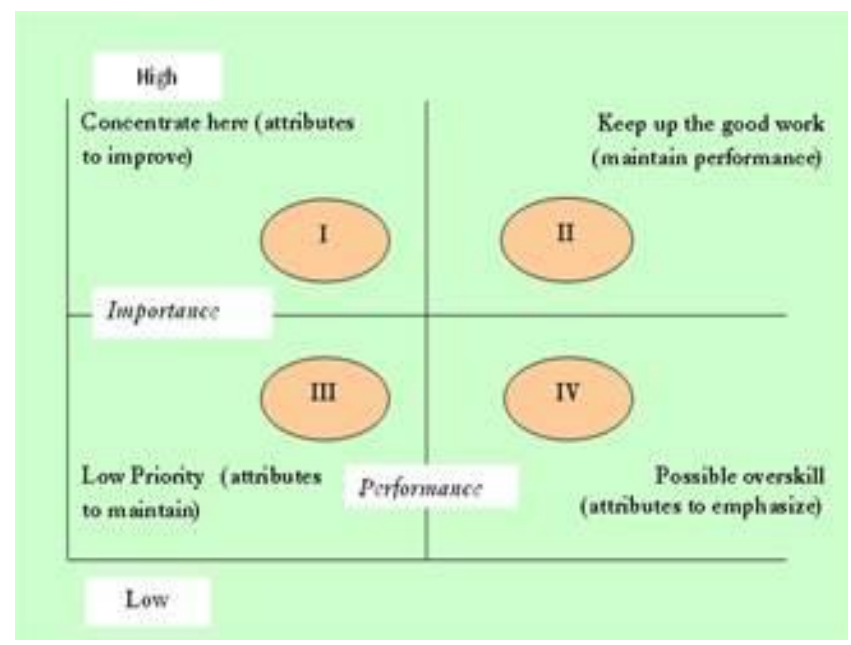

Fig. 1. Importance-Performance Analysis (IPA) Matrix 
TABLE I. PERFORMANCE AND IMPORTANCE LEVEL

\begin{tabular}{|c|c|c|c|c|c|}
\hline \multirow{2}{*}{ Internal } & \multirow{2}{*}{ Parameter } & \multicolumn{2}{|c|}{ SMEs } & \multicolumn{2}{|c|}{ Marketplace } \\
\hline & & Performance & Importance & Performance & Importance \\
\hline $\mathrm{X} 1$ & SMEs personnel's knowledge of Marketplace & 3.74 & 4.47 & 3.13 & 4.13 \\
\hline $\mathrm{x}_{2}$ & $\begin{array}{l}\text { SMEs personnel's knowledge of e-commercee } \\
\text { order, payment and feedback methodd }\end{array}$ & 3.53 & 4.21 & 3.38 & 4.13 \\
\hline $\mathrm{x} 3$ & SMEs understanding of Market's preferences & 3.73 & 4.58 & 3.38 & 4.50 \\
\hline $\mathrm{X} 4$ & SMEs ability to provide attractive packaging & 3.74 & 4.41 & 3.13 & 4.13 \\
\hline $\mathrm{x} 5$ & SMEs ability to provide products continuously and unifomly & 3.85 & 4.32 & 3.00 & 4.13 \\
\hline $\mathrm{x} 6$ & SMEs ability to provide demanded quality & 4.06 & 4.62 & 2.88 & 4.13 \\
\hline$x_{7}$ & SMEs ability to compete on the price of similar products & 3.91 & 4.47 & 3.25 & 4.00 \\
\hline \multirow[t]{2}{*}{$\mathrm{x} 8$} & SMEs ability to give excellent services & 4.03 & 4.50 & 3.13 & 4.50 \\
\hline & & 3.82 & 4.42 & 3.43 & 4.34 \\
\hline \multicolumn{6}{|l|}{ External } \\
\hline $\mathrm{x} 9$ & Internet connection speed & 3.85 & 4.53 & 3.75 & 4.63 \\
\hline $\mathrm{X} 10$ & Electric access (high cost and availability) & 3.30 & 4.18 & 4.00 & 4.50 \\
\hline $\mathrm{x} 11$ & Time period of marketplace payment to SMEs & 3.61 & 4.21 & 4.13 & 4.13 \\
\hline $\mathrm{X} 12$ & Delivery and logistic service availability in SMEs region & 3.97 & 4.44 & 3.38 & 4.63 \\
\hline $\mathrm{X} 13$ & E-commerce regulation & 3.91 & 4.44 & 3.25 & 4.25 \\
\hline X14 & Finance and Capital Access & 3.97 & 4.32 & 3.25 & 4.38 \\
\hline \multirow[t]{2}{*}{$\mathrm{X} 15$} & transaction security in marketplace & 4.06 & 4.55 & 4.38 & 5.00 \\
\hline & & 3.82 & 4.42 & 3.43 & 4.34 \\
\hline Total & & 57.26 & 66.25 & 51.38 & 65.13 \\
\hline Coordinates & & 3.82 & 4.42 & 3.43 & 4.34 \\
\hline
\end{tabular}

There are eight internal factors and seven external factors. The questionnaires were directly distributed to SMEs through associations and communities in Yogyakarta and surrounding areas as well as to marketplaces in the Jakarta area. For descriptive research, the sample is $10 \%$ of the population, correlational research, at least 30 elements of the population, causal-comparative research, 30 elements per group, and for experimental research 15 elements per group (Gay and Diehl, 1992). The total number of respondents is 40 that consists of 32 SMEs and 8 marketplaces.

The questionnaires are assessed using Likert-scale (1-5) on each factors. Suitability level measured using this formula below (Raharjo and Azwir, 2017):

$$
C L_{i}=\frac{X_{i}}{Y_{i}} \times 100 \%
$$

$$
\begin{aligned}
\mathrm{CL}_{\mathrm{i}} & =\text { Conformance level } \\
\mathrm{Xi} & =\text { Performance score } \\
\mathrm{Yi} & =\text { Importance score }
\end{aligned}
$$

Conformance level or suitability level is the result of comparing the performance scores with the importance scores. Furthermore, a Cartesian diagram is necessary in elaborating the importance and performance elements as perceived by respondents. Cartesian diagram which consists of four parts and is bounded by two lines that intersect perpendicular to the points $(\mathrm{X}, \mathrm{Y})$. The formula to determine each of the factors that affect the ability of SMEs to be able to market their products through the marketplace is:

$$
\bar{X}=\frac{\sum X_{i}}{n} \quad \bar{Y}=\frac{\sum Y_{i}}{n}
$$

$\mathrm{X}_{\mathrm{i}} \quad=$ Mean performance rating

$\mathrm{Y}_{\mathrm{i}} \quad$ = Mean importance rating

$\mathrm{n} \quad=$ the number of respondents
The formula to determine the border line on Cartesian diagram are:

$$
X_{1}=\frac{\sum_{i=1}^{k} X_{i}}{k} \quad Y_{1}=\frac{\sum_{i=1}^{k} Y_{i}}{k}
$$

\section{$\mathrm{X}_{1}=$ Mean performance rating of all factors \\ $\mathrm{Y}_{1}=$ Mean importance rating of all factors \\ $\mathrm{k} \quad=$ the number of factors used}

Importance-Performance Analysis matrix consist of four quadrants. Importance refers to the respondent expectation to the certain factor, while performance is associated to how the respondent judges the actual achievement of specific factor. As such, IPA analysis examines on the gap between respondent expectation on the important and judgment on the performance of the factors (Martilla and James, 1977). First quadrant shows factors which have score of importance level higher than the average while score of performance lower than the average. In order to ensure good quality, all factors in this quadrant must be improved. The second quadrant places factors which have score of importance and performance level higher than the average. It shows the ideal condition and these factors should be maintained well. Third quadrant shows factors which have score of importance and performance level lower than the average. These factors need no allocation of cost and investment since respondent consider them as less important. Fourth quadrant indicates factors which have score of importance level lower the average while the score of performance higher than the average (possible over skill). For these factors need no improvement because less important factors have had good performance. The result of internal coordinates and external coordinates have the same score because that is the average number from total external and internal factor.

\section{RESULT AND DISCUSSION}

\section{A. Analysis of Factors based on SMEs perception}

Figure 1 and 2 show internal and external factors according to SMEs perception. Based on analysis of all factors based on SMEs perception, there are three factors which have ideal condition (second quadrant) namely the ability of SMEs to provide quality products in accordance with market demand; the ability of SMEs to compete with similar commodities in terms of price (competitive advantage); and the ability of SMEs to provide good service. While for external factors, the ideal conditions that need to be maintained are seen in three factors, namely internet network access; availability of logistic services in areas where SMEs are located; and regulations governing ecommerce.

In quadrant one for factors whose performance is still low but has high importance, there are two things, namely knowledge of SMEs personnel towards marketplace and the ability or capacity of SMEs entrepreneurs in reading market opportunities/needs. Against these two factors, efforts should be encouraged to improve performance. 
Factors that are considered less important to be improved because currently those have good performance (quadrant four), there are one factor for each internal and external, they are SMEs ability to carry out continuous production with diverse quality (internal), and the ability to access capital and financing (external).

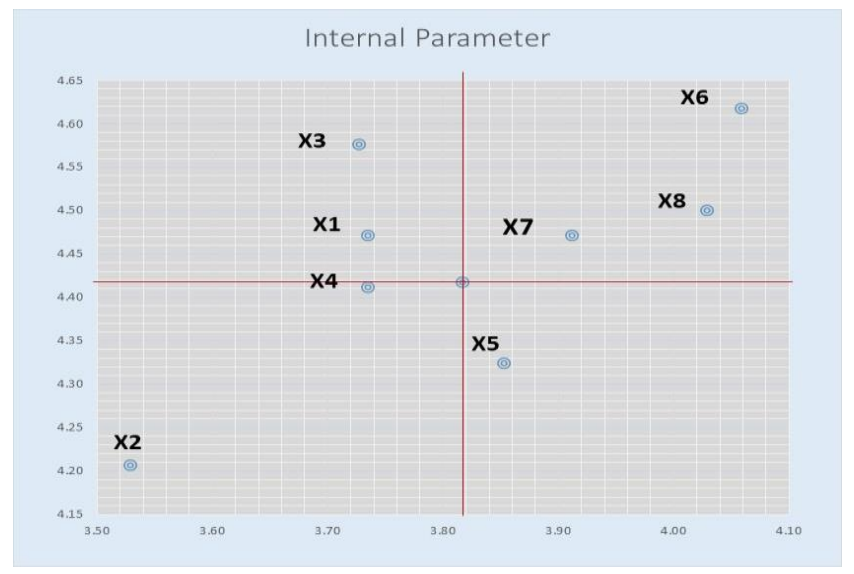

Fig. 2. Internal factors based on SMEs perception

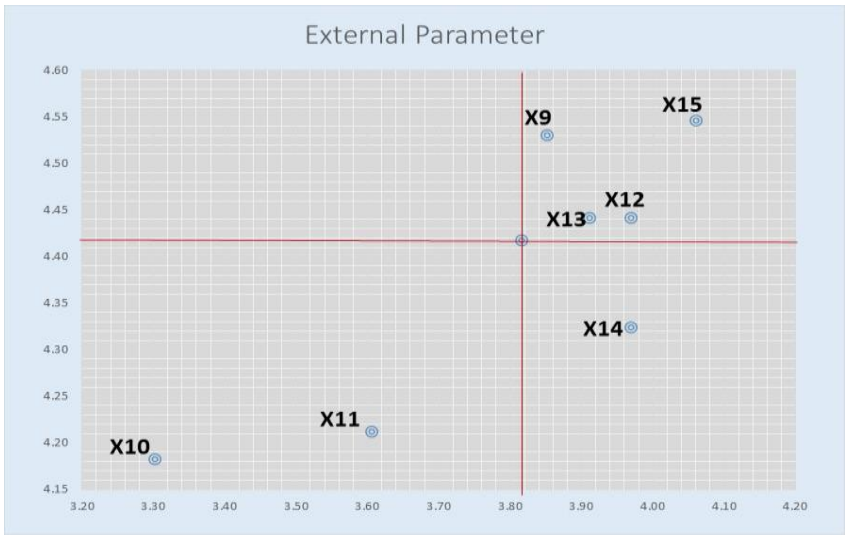

Fig. 3. External factors based on SMEs perception

Internal factors that were considered not to be the focus for improvement (in the third quadrant) were the ability of SMEs personnel on e-commerce specifically in terms of ordering and payment methods, and the ability of SMEs to package product attractively. While for external factors, access for electricity and term of payment from marketplace to SMEs are still perceived to have low performance so there still need effort to improve the current performance.

\section{B. Analysis of factors based on Marketplace}

Based on the results of factor analysis based on marketplace perceptions, results are obtained as seen in Fig. 3 and 4. Based on the results of the IPA analysis, the factors that have ideal conditions and their performance must be maintained are only on external factors, namely access to internet, access to electricity, and security in terms of transactions through the marketplace.

There are two internal factors which are in quadrant one, namely, the ability of SMEs entrepreneurs in reading market opportunities, and the ability of SMEs to provide good service. These two internal factors need to be improved according to marketplace perception. While the availability of logistic services in the region where the SMEs is located, and access to capital and financing are external factors that are encouraged to be developed.

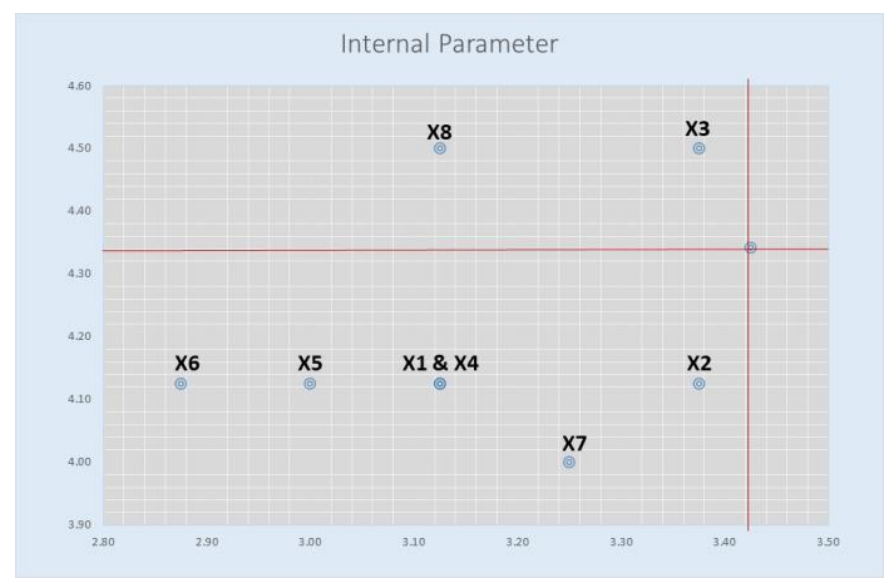

Fig. 4. Internal factors based on Marketplace perception

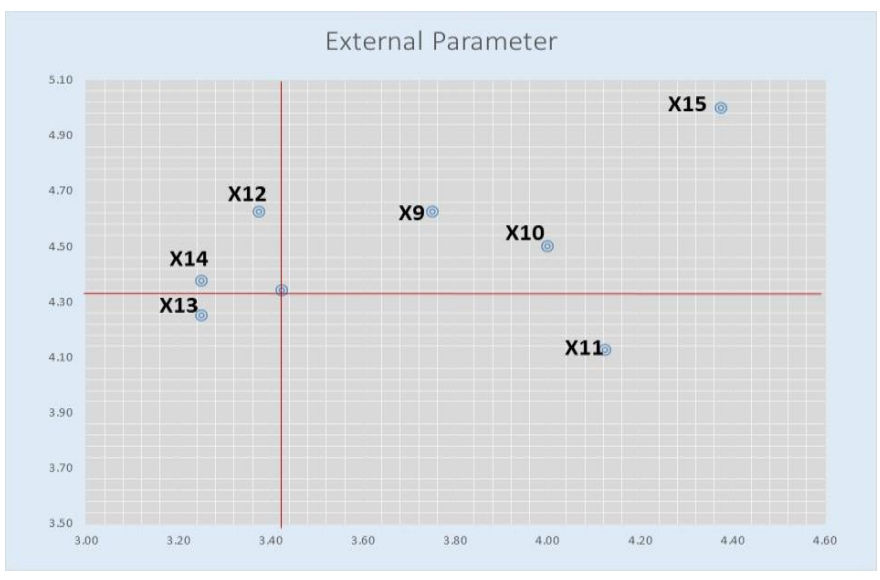

Fig. 5. External factors based on Marketplace perception

There are several factors that are considered not a priority (less important) for marketplace and have low performance that lies in quadrant three. There are six factors in internal factors, namely knowledge of SMEs personnel towards the marketplace; ability of SMEs to package products attractively; SMEs personnel capabilities regarding ecommerce: ordering, and payment methods; ability of SMEs to provide a number of products continuously with uniform quality; ability of SMEs to compete with similar commodities in terms of price (competitive advantage), and the ability of SMEs to provide quality products on demand. While only one external factor in quadrant three that is regulations governing the e-commerce industry.

Of all factors, marketplaces consider one factor which is less important but has good performance (in quadrant four). That is the term of payment from marketplace to the SMEs. They assume that the time span of 2 to 7 days is still a reasonable limit in the terms of returning money to SMEs.

Based on the analysis result, there are differences of opinion and perceptions among both parties (SMEs and Marketplaces) in determining the most influential factors. Differences in perception among those are possible due to 
differences in the level of understanding, experience and interest of each party. For example, the marketplace consider that SMEs have sufficient understanding of the digital marketing on how they sell their products through ecommerce platform (marketplace) because they have been quite intensive in approaching and fostering SMEs in providing education/training on how they can sell their products in the marketplace. Meanwhile, according to SMEs, the program that is provided in the form of training is still not sufficient for SMEs. This can be a signal for the government as a facilitator as well as regulator to outreach more SMEs in providing training on e-commerce so it can be more massively and intensively.

\section{Government Policy to Support SMEs in Adopting E- commerce}

Some program has been conducted by central and local government to support SMEs to connect to online marketplace. Local government cooperates with existing Indonesia marketplace such as Bukalapak, Tokopedia, Shopee, Blibli and Blanja.com in giving education and training to SMEs. Various programs under Ministry of Industry, Ministry of Information and Communication have been launched since 2017 to support SMEs to be connected online through E-Smart, SMEs Go Online, and Palapa Ring Programs. These programs are carried out by local government by involving SMEs surround Yogyakarta city. However, existing training program that conducted by local government have the same curriculum with other training provider. Thus, SMEs get the same education repeatedly without advancing their skill and knowledge.

\section{CONCLUSION AND POLICY RECOMMENDATION}

This study was conducted as an effort to find the determinant factors that influence the adoption of ecommerce by SMEs in Indonesia. It was concluded that the main factors inhibiting SMEs in adopting e-commerce are the lack of knowledge about the marketplace and the ability to look over and understand the market opportunities and market preference.

The adoption of e-commerce by SMEs need to be encouraged by government intervention through socialization and training intensively in tiered system by cooperation between government and other stakeholder such as private (marketplace) and social community. The training must have the ability to improve SMEs capacity by giving coaching clinic and also specific training to SMEs regarding marketplace; online marketing system; how to read market opportunity, and attractive packaging that benefit SMEs on increasing target consumer and penetrating the market through online platform.

\section{ACKNOWLEDGMENT}

This study has been prepared based on research project conducted by Center for Analysis of Domestic Trade, Ministry of Trade, Republic of Indonesia. We would like to express our gratitude to all respondents and interviewees consists of SMEs, Association (APIKRI), local government, as well as marketplace (Bukalapak, Tokopedia, Blibli, Kuka, Shopee, Sarinah, and Qlapa) by giving us valuable information during carrying out this research.

\section{REFERENCES}

[1] McKinsey, Unlocking Indonesia's Digital Opportunity, https://www.mckinsey.com/ /media/McKinsey/Locations/Asia/Indon esia/Our\%20Insights/Unlocking\%20Indonesias\%20digital\%20opport unity/Unlocking_Indonesias_digital_opportunity.ashx

[2] IdEA, Media Sosial, Platform Paling Banyak Digunakan Saat Transaksi E-commerce, databoks.katadata.co.id/datapublish/2019/04/01/media-sosialplatform-paling banyak-digunakan-saat-transaksi-e-commerce.

[3] APJII, Laporan Survey : Penetrasi dan Profil Perilaku Pengguna Internet di Indonesia, Buletin APJII, Vol 40, May 2019

[4] IDNTimes, Pertumbuhan E-commerce Indonesia Meningkat Tajam, Siapa di Posisi Teratas?, https://www.idntimes.com/business/economy/yoshi/pertumbuhan-ecommerce-indonesia- $1 /$ full

[5] BPS, Tabel perkembanhgan UMKM pada periode 1997 - 2013, https://www.bps.go.id/statictable/2014/01/30/1322/tabelperkembangan-umkm-pada-periode-1997--2013.html

[6] Bank Indonesia (B. I.) and LPPI, Profil Bisnis Usaha Mikro, Kecil, dan Menengah (UMKM), pp. 18-20, 2015.

[7] M. Kiveu, and G. Ofafa. Enhancing Market Access in Kenyan SMEs Using ICT. Global Business and Economics Research Journal, Vol. 2(9), pp. 29-46, 2012

[8] G. H. Ho, The Adoption of E-Commerce in SMEs in Vietnam, Thesis, International Business Management, Turku University of Applied Sciences, 2017.

[9] M. A. F. Mukhtar, M. A. b. Ashaari, A. R. b. Abd Rahman, and Dr. A. R. C. Husin, E-marketplace in Malaysia: Challenges and Solutions, Journal of Information Systems Research and Innovation 10(1), 1-7, February 2016.

[10] P. Ueasangkomsate. Adoption E-Commerce for Export Market of Small and Medium Enterprises in Thailand. Procedia- Social and Behavioral Sciences 207, pp. 111-120, 2015.

[11] J.A. Martilla and J.C. James, Importance-Performance Analysis. Journal of Marketing, Vol.41 (1), pp.77-79, 1977.

[12] L. R. Gay, and P. L. Diehl, Research Methods for Business and Management, MacMillan Publishing Company, New York. 1992.

[13] H. M. Raharjo, and H. H. Azwir, A Combination of Importance and Performance Analysis and Potential Gain in Customer Value for Determining Service Attributes Priority Level for PT. X, Journal of Industrial Engineering, Scientific Journal on Research and Application of Industrial System, Vol. 2 (1): 1-9, 2017 